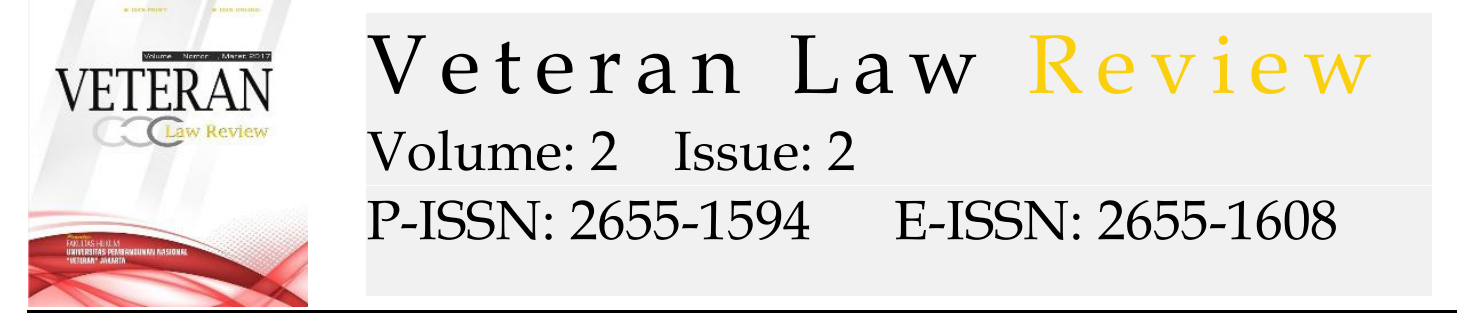

\title{
The Sovereignty Aspect on Earth (Arctic, Antarctic, Seabed and Ocean Floor) and on Moon: Comparative Study
}

\author{
Ketut Andri Sena ${ }^{1}$, I Gede Pasek Eka Wisanjaya ${ }^{2}$ \\ ${ }^{1}$ Faculty of Law, Udayana University, E-mail: ketutandrisena@gmail.com \\ ${ }^{2}$ Faculty of Law, Udayana University, E-mail: pasek.wisanjaya@yahoo.com
}

\begin{tabular}{|c|c|}
\hline ARTICLE INFO & ABSTRACT \\
\hline $\begin{array}{l}\text { Keywords: } \\
\text { Sovereignty; Arctic; } \\
\text { Antarctic; Seabed; Ocean } \\
\text { Floor; Moon } \\
\text { How to cite: } \\
\text { Sena, K. A., \& P. E. I Gede. } \\
\text { (2019). The Sovereignty } \\
\text { Aspect on Earth (Arctic, } \\
\text { Antarctic, Seabed and } \\
\text { Ocean Floor) and on } \\
\text { Moon: Comparative } \\
\text { Study. Veteran Law Review. } \\
\text { 2(2). hlm. 6-20 }\end{array}$ & $\begin{array}{l}\text { The increased attempts to utilize moon has emerged issue relating to } \\
\text { its sovereign status. This research attempts to compare sovereignty } \\
\text { aspect on earth (Arctic, Antarctic, seabed) and on moon, by applying } \\
\text { normative legal research. On Earth, several states have claimed their } \\
\text { territories upon the Arctic and the Antarctic. However, those claims } \\
\text { remain unresolved, and in any event, the Arctic and the Antarctic } \\
\text { territories are still open for public. On the other hand, seabed and } \\
\text { ocean floor have been regulated by international legal instruments } \\
\text { that no sovereignty may be claimed upon. On Moon, several treaties } \\
\text { and declarations have governed that no sovereignty may be claimed } \\
\text { upon, and that any activity there must be for the peaceful purpose of } \\
\text { mankind. Subsequently, the Arctic, Antarctic, seabed and ocean } \\
\text { floor, and also moon have been declared as common heritage of } \\
\text { mankind. } \\
\text { Copyright @2019 VELREV. All rights reserved. }\end{array}$ \\
\hline
\end{tabular}

\section{Introduction}

Outer space, including the moon is the known and unknown areas of the universe beyond the airspace. ${ }^{1}$ Putting human on moon is acclaimed as human greatest milestone ever made, but that is not a cheap effort. ${ }^{2}$ Apollo mission which was for scientific research ${ }^{3}$ and only sent 12 persons to Moon surface cost USD 25 billions (estimated to be valued USD 170 billions at modern monetary value). ${ }^{4}$ Apollo mission 1 was undertaken in $1967^{5}$ and

\footnotetext{
${ }^{1}$ Bryan A. Garner (ed), 2009, Black's Law Dictionary, $9^{\text {th }}$ edition, Thomson Reuters, Toronto, p. 1212.

2 Richard Gray, 2016, “We Could Be Living on the Moon by 2022: NASA Claims A 'Cheap' $\$ 10$ Billion Lunar Base Will Be Ready for Humans in Just Six Years", URL: http://www.dailymail.co.uk/sciencetech/article-3507665/Could-living-moon-2022Nasa-scientists-reveal-plans-build-lunar-base-six-years-10-billion.html accessed on 3 May 2017

${ }^{3}$ David Hitt, 2015, "What Was the Appolo Program?", NASA Knows (Grades 5-8), URL: https://www.nasa.gov/audience/forstudents/5-8/features/nasa-knows/what-wasapollo-program-58.html accessed on 3 May 2017.

${ }^{4}$ Richard Gray, loc. Cit.
} 
Apollo mission 17 which was the last mission ${ }^{6}$ of the Apollo mission series was undertaken in $1972 .^{7}$

Nowadays, a plan rises not only to go back to moon, but also to stay there. ${ }^{8}$ That plan came out from China through China National Space Administration (CNSA) and European States who are gathered in European Space Agency (ESA). ${ }^{9}$ CNSA and ESA cooperate to execute plan named 'Moon Village', ${ }^{10}$ while NASA also plan to establish the moon base. ${ }^{11}$ From the private sector, a company named SpaceX plans to undertake the same. ${ }^{12}$

As the activities on moon are expected to be massive in the future, the issue of sovereignty on moon needs to be discussed. On earth, the Arctic, Antarctic, seabed and ocean floor may have similar situation with the moon concerning sovereignty issue. Subsequently, a comparative study could be done to analyze it.

\subsection{Formulation of the Problems}

1. What is Sovereignty?

2. What legal instruments do concern the sovereignty aspect on earth (Arctic, Antarctic, seabed and ocean floor) and on moon?

3. What are the similarities and differences concerning sovereignty aspect between on earth (Arctic, Antarctic, seabed and ocean floor) and on moon?

\subsection{Objective}

The objective of this legal research is to analyze the sovereignty aspect on earth (Arctic, Antarctic, seabed and ocean floor) and on moon, to which the international law perspective is applied. It aims to explain whether the state, possesses sovereignty on moon as it does on earth.

5 NASA, 2012, "Apollo 1", URL: https://www.nasa.gov/mission_pages/apollo/missions/apollo1.html accessed on 3 May 2017.

6 Amal Nur Ngazis, 2016, “13-12-1972: Misi Terakhir Manusia Mengorbit Bulan”, URL: http:/ / teknologi.news.viva.co.id/news/read/858674-13-12-1972-misi-terakhirmanusia-mengorbit-bulan accessed on 3 May 2017.

7 NASA, 2011, "Apollo 17", URL: https://www.nasa.gov/mission_pages/apollo/missions/apollo17.html accessed on 3 May 2017.

8 Matt Williams, 2016, "Moonbase by 2022 for $\$ 10$ Billion, Says NASA", URL: https://www.universetoday.com/128011/moonbase-2022-10-billion-says-nasa/ accessed on 4 May 2017.

${ }^{9}$ Andrew Griffin, 2017, "China and Europe to Build A Base on the Moon and Launch Other Projects into Space", URL: http://www.independent.co.uk/news/science/moon-baseoutpost-china-europe-chinese-space-agency-collaboration-together-a7702936.html accessed on 4 May 2017.

10 Jasper Hamill, 2017, "China and Europe Want to Build A Moon Base Together", URL: http:/ / nypost.com/2017/04/27/china-and-europe-want-to-build-a-moon-basetogether/ accessed on 4 Mei 2017.

${ }^{11}$ Edd Gent, 2018, "Moon Bases Being Planned Now May Show Us How to Live Off-Planet", URL: https://www.nbcnews.com/mach/science/moon-bases-being-planned-nowmay-show-us-how-live-ncna855826 accessed on 22 September 2018.

12 The Guardian, 2017, “Elon Musk: SpaceX Can Colonize Mars and Build Moon Base," URL: https:/ / www.theguardian.com/technology/2017/sep/29/elon-musk-spacex-cancolonise-mars-and-build-base-on-oon accessed on 22 September 2018. 


\section{Method}

This legal research applies normative legal research as the type of research method. Normative legal research is a legal research conducted by examining primary and secondary sources. ${ }^{13}$

This legal research applies statute approach, analytical approach and conceptual approach as type of research approach. ${ }^{14}$

This legal research uses secondary data. Secondary data include:

1. Primary legal materials, including conventions, treaties, agreements and declarations in the scope of public international law generally and international space law specifically;

2. Secondary legal materials, including legal materials that explain concerning the primary legal materials, for instance legal researches, cases or literatures that are relevant with the issues analyzed in this legal research;

3. Tertiary legal materials, including legal materials that will provide guidance and explanation concerning the primary and secondary materials such as dictionary, encyclopedia and so forth.

The steps in normative legal research include collecting, reading, and analyzing literatures that are related with the issues in this research as well as quoting several supporting opinions or statements to answer the issues in this research. Subsequently, all of the materials are arranged systematically as the legal basis to answer the issues.

The techniques of analyzing legal materials used in this legal research are descriptive and systematic. The descriptive technique is a technique explaining about the real condition or position from the legal or non-legal proportions. The systematic technique is a technique used to find the relation of the concept of law of legal proportion between regulations.

\section{Main Heading of the Analysis or Results}

\subsection{Basic Concept of Sovereignty}

Sovereign means characteristic of or endowed with supreme authority. ${ }^{15}$ Sovereignty expresses the supremacy of the governmental institutions (internally) and the supremacy of the state as a legal person (externally). ${ }^{16}$ In

13 Soerjono Soekanto and Sri Mamudji, 2006, Penelitian Hukum Normatif Suatu Tinjauan Singkat, Raja Grafindo Persada, Jakarta, p.13.

${ }^{14}$ Peter Mahmud Marzuki, 2009, Penelitian Hukum, Kencana Prenada Media Group, Jakarta, p. 93.

${ }^{15}$ Bryan A. Garner (ed), op. cit., p. 1523.

${ }^{16}$ J. H. W. Verzijl, 1970, International Law in Historical Perspective, Leiden, Vol. 3, p. 297; Malcolm N. Shaw, 1982, "Territory in International Law", Netherlands Yearbook of International Law, Vol. 13, (Malcolm N. Shaw I), p. 61; Nguyen Quoc Dinh, P. Daillier and A. Pellet, 2002, Droit International Public, $7^{\text {th }}$ edition, Paris, p. 464, 529; Malcolm N. Shaw, 2003, International Law, th $^{\text {th }}$ edition, Cambridge University Press, Cambridge, (Malcolm N. Shaw II), p. 409. 
Nicaragua, ${ }^{17}$ sovereignty means that each state is permitted to decide freely. Those free decisions include, but not limited to, the choice of a system (economic, politic, social and cultural) and also formulation of the foreign policy. ${ }^{18}$

In Island of Palmas, ${ }^{19}$ sovereignty in its relation to a portion of the globe surface is the legal condition which is necessary for the inclusion of the mentioned portion in a territory of any particular state. ${ }^{20}$ Sovereignty in its relation to a territory is called 'territorial sovereignty' in the present award. ${ }^{21}$ Sovereignty in the relations between States signifies independence. Independence in its regard to a portion of the globe is the right to exercise the functions of a State, to the exclusion of the other States. ${ }^{22}$

From all the meanings of sovereignty as explained earlier, the state which exercises sovereignty could be interpreted that the state, by supremacy, may decide freely concerning all lawful measures taken in its territory with the exclusion of any other states.

${ }_{17}$ Military and Paramilitary Activities in and against Nicaragua (Nicaragua $v$. United States of America), Merits, Judgment of 27 June 1986, I.C.J. Reports 1986, \205.

18 Christian Tomuschat, 1993, Modern Law of Self Determination, Martinus Nijhoff Publishers, Leiden, p. 259; Andre De Hoogh, 1996, Obligation Erga Omnes and International Crimes: A Theoretical Inquiry Into the Implementation and Enforcement of the International Responsibility of States, Martinus Nijhoff Publishers, Leiden, p. 176; Philip Kunig, 2008, "Intervention, Prohibition of", Max Planck Encyclopedia of Public International Law, Oxford University Press, Oxford, q2; M. Sornarajah, 2010, The International Law on Foreign Investment, Cambridge University Press, Cambridge, p. 70; Martin Dixon, Robert McCoquodale and Sarah Williams, 2011, Cases and Materials on International Law, Oxford University Press, Oxford, (Martin Dixon I), p. 516; Marcelo Kohen, 2012, "The Principle of NonIntervention 25 Years after the Nicaragua Judgment", Leiden Journal of International Law, Vol. 25, p. 160; Silke Marie Christiansen, 2016, Climate Conflicts - A Case of International Environmental and Humanitarian Law, Springer, Berlin, p. 168.

${ }^{19}$ United Nations Office of Legal Affairs, 1928, "Island of Palmas", Report of International Arbitral Awards, Vol. 2, pp. 829, 838.

20 Surya Prakash Sharma, 1997, Territorial Acquisition, Disputes and International Law, Martinus Nijhoff Publishers, Leiden, P. 3; Christian J. Tams and James Sloan, 2013, The Development of International Law by the International Court of Justice, Oxford University Press, Oxford, p. 152.

21 Vincent Coussirat-Coustaere and Pierre Michel Eissemann, 1989, Repertory of International Arbitral Jurisprudence, Vol. 2, Brill, Leiden, P. 70; Cairo A. R. Robb et. al., 1999, International Environmental Law Reports, Vol. 1, Cambridge University Press, Cambridge, p. 143; Amos Enabulele and Bright Bazuaye, 2014, Teachings on Basic Topics in Public International Law, Amos Enabulele, p. 461.

${ }^{22}$ Rosanne van Alebeek, 2008, The Immunity of States and Their Officials in International Criminal Law and International Human Rights Law, E. M. Meijers Instituut, Leiden, p. 333; Elizabeth Fisher, Bettina Lange and Eloise Scotford, 2013, Environmental Law: Text, Cases and Materials, Oxford University Press, Oxford, p. 176; Martin Dixon, Robert McCoquodale and Sarah Williams, 2016, Cases and Materials on International Law, Oxford University Press, Oxford, (Martin Dixon II), p. 244; Petra Butler and Caroline Morris, 2017, Small States in a Legal World, Springer, Berlin, p. 122. 


\subsection{Sovereignty on Earth (Arctic, Antarctic, Seabed and Ocean Floor)}

With regard to the Arctic region, Denmark possesses Greenland and its associated islands within the region, while Norway has asserted sovereign rights over Spitzbergen and other islands. ${ }^{23}$ The Norwegian sovereignty was recognized by 9 (nine) nations in 1920, although the Soviet Union had protested. ${ }^{24}$ The former USSR $^{25}$ and Canada ${ }^{26}$ has made the concept of contiguity to assert claims over areas forming geographical units with those already occupied, in the form of the so-called 'sector principle'. The other Arctic states of Finland, Norway, the United States of America and Denmark have abstained from such assertions. ${ }^{27}$ Consequently, it is doubtful whether the sector principle can be regarded as sovereignty. ${ }^{28}$ The former USSR made some claims to relatively immovable ice formations of the Arctic region as being subject to its national sovereignty, however the overall opinion remains to treat these as part of the high seas open to all. ${ }^{29}$

With regard to the Antarctic region, several states namely Argentina, ${ }^{30}$ Australia, ${ }^{31}$ Chile, $^{32}$ France, $^{33}$ New Zealand, ${ }^{34}$ Norway $^{35}$ and the United Kingdom $^{36}$ have made claims. However, the 1959 Antarctic Treaty was signed, in which one of the rules is to govern territorial claim. ${ }^{37}$ Article IV(1)

23 Malcolm N. Shaw, 2008, International Law, $6^{\text {th }}$ edition, Cambridge University Press, Cambridge, (Malcolm N. Shaw III), p. 535.

${ }^{24}$ G. H. Hackworth, 1940, Digest of International Law, Vol. 1, Washington, DC, p. 465; D. P. O’Connell, 1970, International Law, $2^{\text {nd }}$ edition, Stevens, London, $\mathrm{p}$. 499.

${ }^{25}$ G. H. Hackworth, op. cit., p. 461.

26 American Society of International Law, 1970, "Documents Concerning Canadian Legislation on Arctic Pollution and Territorial Sea and Fishing Zones”, International Legal Materials, Vol. 9, Cambridge University Press, Cambridge, pp. 607, 613; I. Head, 1962, "Canadian Claims to Territorial Sovereignty in the Arctic Regions", McGill Law Journal, Vol. 9, p. 200.

27 Susan Breau, 2013, Q \& A Revision Guide International Law 2013 and 2014, Oxford University Press, Oxford, p. 95.

28 R. Y. Jennings and A.D. Watts, 1992, Oppenheim's International Law, Vol. 1, 9 edition, Oxford University Press, Oxford, p. 693.

29 W. Lakhtine, "Rights over the Arctic", American Journal of International Law, Vol. 24, 1930, p. 461; Balch, "The Arctic and Antarctic Regions and the Law of Nations", American Journal of International Law, Vol. 4, 1910, pp. 265-266.

${ }^{30}$ Malcolm N. Shaw III, op. cit., pp. 535-536.

31 G. Triggs, 1982, “Australian Sovereignty in Antarctica - Part II", Melbourne University Law Review, Vol. 13, p. 302.

${ }^{32}$ Luis S. Mericq, 1987, Antarctica: Chile's Claim, National Defense University Press, Washington, p. 42.

33 G. Triggs, 1981, "Australian Sovereignty in Antarctica - Part I", Melbourne University Law Review, Vol. 13, p. 123; Francisco Orrego Vicuna, 1988, Antarctic Mineral Exploitation: The Emerging Legal Framework, Cambridge University Press, Cambridge, p. 139.

34 Klaus J. Dodds and Kathryn Yusoff, 2004, Settlement and Unsettlement in Aotearoa/New Zealand and Antarctica, University of London, Surrey, p. 141.

35 Odd Gunnar Skagestad, 2013, "Sovereignty, Jurisdiction and Cooperation: The Antarctic Treaty, Preconditions, Substance and Future Relevance", New Ground Research Journal of Scientific Research and Articles, Vol. 1, p. 7.

${ }^{36}$ Christopher C. Joyner, 1992, Antarctica and the Law of the Sea, Martinus Nijhoff Publishers, Leiden, p. 48.

37 Adriana Fabra and Virginia Gascon, 2008, "The Convention on the Conservation of Antarctic Marine Living Resources (CCAMLR) and the Ecosystem Approach", 
of the Antarctic Treaty provides that no rule contained in the Antarctic Treaty shall be interpreted as first, a renunciation by any Contracting Party of previously asserted rights of or claims to territorial sovereignty in Antarctica; secondly, a renunciation or diminution by any Contracting Party of any basis of claim to territorial sovereignty in Antarctica which it may have whether as a result of its activities or those of its nationals in Antarctica, or thirdly; prejudicing the position of any Contracting Party's recognition or nonrecognition of any other State's claim to territorial sovereignty in the Antarctica. ${ }^{38}$ In the same treaty, Article IV(2) then provides that no acts or activities may be exercised, while the Antarctic Treaty is in force, that shall constitute a basis to assert, support or deny a claim to territorial sovereignty in the Antarctica or create any rights of sovereignty in the Antarctica. No new other claim, or enlargement of the existing claim, to territorial sovereignty of the Antarctica shall be asserted while the Antarctic Treaty is in force $^{39}$ The rule of non-sovereignty in the Antarctic Treaty is reiterated in Article IV of Convention on the Conservation of Antarctic Marine Living Resources. $^{40}$ Accordingly, both Antarctic Treaty Convention on the Conservation of Antarctic Marine Living Resources remain unclear whether or not they have to reject the existing claim of sovereignty on Antarctic. Consequently, it left unresolved the pre-existing territorial sovereignty claimed by several nations. ${ }^{41}$

As the Arctic and Antarctic regions may not be subject of national appropriation or sovereignty claim, consequently, both the Arctic and Antarctic regions, could arguably be considered as the common heritage of mankind. ${ }^{42}$ However, in regard to the base, no relevant legal instrument specifically provides for the "free access" to other state's base each other.

With regard to the seabed and ocean floor, there is no any existing claim made by any state. In any event, there exists legal instruments providing for the seabed and ocean floor. In 1970, the United Nations General Assembly adopted Resolution 2749 (XXV), which annexed the Declaration of Principles

The International Journal of Marine and Coastal Law, Vol. 23, Martinus Nijhoff Publishers, Leiden, p. 582.

38 Christopher C. Joyner, op. cit., p. 63; Ole Kristian Fauchald, David Hunter and Wang Xi, 2011, Yearbook of International Environmental Law 2009, Vol. 20, Oxford University Press, Oxford, p. 11; Ben Saul and Tim Stephens, 2015, Antarctica in International Law, Bloomsbury Publishing, London, p. 261

39 UN Doc. A/41/722, 17 November 1986, Question of Antarctica, I141; Phillip Bender, 2007, "A State of Necessity: IUU Fishing in the CCAMLR Zone", Ocean and Coastal Law Journal, Vol. 13, p. 251; Gianfranco Tamburelli, 2008, The Antarctic Legal System: The Protections of the Environment of the Polar Regions, Giuffre Editore, Milan, pp. 129-130; Hugo Caminos, 2017, Law of the Sea, Routledge, London, p. 530.

40 Christopher C. Joyner, op. cit., p. 96; Gunter Hoog and Angela Steinmetz, 1993, International Conventions on Protection of Humanity and Environment, Walter de Guyter, Berlin, p. 423; Donald R. Rothwell, 1996, The Polar Regions and the Development of International Law, Cambridge University Press, Cambridge, pp. 125-126; Charles Lawson, 2012, Regulating Genetic Resources: Access and Benefit Sharing in International Law, Edward Elgar Publishing, Cheltenham, p. 36.

41 Paul Stephen Dempsey, 2008, Public International Air Law, Mcgill University Institute and Centre for Research in Air and Space Law, Montreal, p. 31.

42 Susan Breau, op. cit., p. 94. 
Governing the Seabed and the Ocean Floor, and the Subsoil Thereof, beyond the Limits of National Jurisdiction. The Declaration rules that seabed and ocean floor shall not be subject to appropriation by any means by States nor persons, natural or juridical, and also no State shall claim or exercise sovereignty over any part thereof." 43 The rule was reaffirmed in the 1982 Convention on the Law of the Sea, Articles 136 and 137, in which it was provided that no sovereign rights would be recognized with regard to the area and that exploitation could only be exercised in accordance with the structures and rules constituted by the Convention. ${ }^{44}$

Furthermore, the 1970 Declaration states that the seabed and ocean floor are the common heritage of mankind. ${ }^{45}$ However, in regard to the base, no relevant legal instrument specifically provides for "free access" to other state's base each other.

\subsection{Sovereignty on Moon}

With regard to the moon, there is no any existing claim made by any state. In any event, there exists legal instruments providing for the moon. The United Nations General Assembly adopted several resolutions which concerned the sovereignty on moon. In Resolution 1721 A (XVI), the United Nations General Assembly states that outer space and celestial bodies are not subject to national appropriation. ${ }^{46}$

In 1963, the United Nations General Assembly adopted Resolution 1962 (XVIII) which annexed the Declaration of Legal Principles Governing the Activities of States in the Exploration and Use of Outer Space. ${ }^{47}$ In such declaration, Article 3 rules that outer Space and celestial bodies are not subject to national appropriation by claim of sovereignty. ${ }^{48}$

In 1996, the United Nations General Assembly adopted Resolution 51/122 which annexed the Declaration on International Cooperation in the Exploration and Use of Outer Space for the Benefit and in the Interest of All States, Taking into Particular Account, the Needs of Developing Countries. ${ }^{49}$

43 Bernard H. Oxman, 1989, “The high Seas and the International Seabed Area", Michigan Journal of International Law, Vol. 10, p. 533; United Nations General Assembly, 1997, Key Resolutions of the United Nations General Assembly 1946-1996, Cambridge University Press, Cambridge, p. 436; Yoshifumi Tanaka, 2011, "Protection of Community Interests in International Law: The Case of the Law of the Sea", Max Planck Yearbook of United Nations Law, Vol. 15, p. 342.

${ }^{44}$ Malcolm N. Shaw III, op. cit., p. 533.

45 Shigeru Oda, 1972, The International Law of the Ocean Development: Basic Documents, Volume 1, Brill, Leiden, p. 196; Robin Rolf Churchill and Alan Vaughan Lowe, 1983, The Law of the Sea, Manchester University Press, Manchester, p. 158; Yoshifumi Tanaka, 2012, The International Law of the Sea, Cambridge University Press, Cambridge, p. 172.

${ }^{46}$ Bin Cheng, 1999, "Outer Void Space: The Reason for This Neologism in Space Law", Australian International Law Journal, p. 2.

47 Obed Y. Asamoah, 2012, The Legal Significance of the Declarations of the General Assembly of the United Nations, Springer, Berlin, p. 133.

48 Thomas Gangale, 2009, The Development of Outer Space: Sovereignty and Property Rights in International Space Law, ABC-CLIO, California, p. 25.

49 UNGA Res. 51/122, 13 December 1996, Declaration on International Cooperation in the Exploration and Use of Outer Space for the Benefit and in the Interest of All States, Taking into Particular Account, the Needs of Developing Countries. 
In this resolution, the Preamble set forth that member states are desirous to facilitate the application of the legal principle that the exploration and use of the outer space, including the Moon and other celestial bodies shall be the province of all mankind. ${ }^{50}$ In the annexed declaration, Article 1 rules that International cooperation of states in relation to the exploration and use of outer space for the peaceful purposes shall be conducted in accordance with international law, including the United Nations Charter and also the Treaty on the Principles Governing the Activities of States in the Exploration and Use of Outer Space, including the Moon and Other Celestial Bodies 1967 (the "Outer Space Treaty"). The same Article also rules that the outer space shall be the province of all mankind, in the light that account should be taken of the needs of developing countries.

According to treaties, in Outer Space Treaty, Article I provides that the exploration and use of the outer space, including the moon and other celestial bodies shall be the province of all mankind. ${ }^{51}$ The Outer Space Treaty through Article II also provides that outer space, including the Moon and other celestial bodies, is not subject to any national appropriation by claim of sovereignty. ${ }^{52}$

The rule of non-sovereignty in the Outer Space Treaty is reiterated in the Agreement Governing the Activities of States on the Moon and Other Celestial Bodies (the "Moon Agreement"). Article 4 provides that the exploration and use of the moon shall be the province of all mankind. ${ }^{53}$ The Moon Agreement through Article 11(2) also provides that the Moon is not subject to any national appropriation by claim of sovereignty. ${ }^{54}$

The subsequent implication of the rules above is that as similar as on earth (Arctic, Antarctic, seabed and ocean floor), sovereignty could not also be claimed on the Moon. Additionally, Article 11(1) of the Moon Agreement also provides, similar as on earth (Arctic, Antarctic, seabed and ocean floor), that the Moon and its natural resources are the common heritage of mankind. ${ }^{55}$

50 Gabriel Lafferranderie and Daphne Crowther, 1997, Outlook on Space Law Over the Next 30 Years, Martinus Nijhoff Publishers, Leiden, p. 77.

51 Virginie Blanchette-Seguin, 2017, "Reaching for the Moon: Mining in Outer Space”, International Law and Politics, Vol. 49, p. 961.

52 Stephen Gorove, "Interpreting Article II of the Space Treaty", Fordham Law Review, Vol. 37, p. 349; Ricky J. Lee, 2004, "Article II of the Outer Space Treaty: Prohibition of State Sovereignty, Private Property Rights, or Both?", Australian Journal of International Law, Vol. 11, pp. 128-129; Marietta Benko et. al., 2005, Space Law: Current Problems Perspective for Future Regulation, Eleven International International Publishing, Hague, p. 221.

53 Gijsbertha Cornelia Maria Reijnen, 1992, The United Nations Space Treaties Analyzed, Atlantica Seguier Frontieres, Paris, p. 293.

${ }^{54}$ Ram S. Jakhu, 2016, Routledge Handbook of Space Law, Taylor \& Francis, Oxfordshire, p. 29; Tosaporn Leepuengtham, 2017, The Protection of Intellectual Property Rights in Outer Space Activities, Edward Elgar Publishing, Cheltenham, pp. 17-18.

55 Carol R. Buxton, 2004,"Property in Outer Space: The Common Heritage of Mankind Principle vs. the First in Time, First in Right, Rule of Property", Journal of Air Law and Commerce, Vol. 69, p. 699; John E. Noyes, 2012, "The Common Heritage of Mankind: Past, Present, and Future", Denver Journal of International Law and Policy, Vol. 40, p. 449. 
In regard to the base, unlike on earth (Arctic, Antarctic, seabed and ocean floor), there exists legal instrument providing for "free access" to other state's base. Article I of the Outer Space Treaty provides that outer space, including the Moon and other celestial bodies, shall be free for exploration and use and in which there shall also be free access to all areas. ${ }^{56}$ However, such Article must be read in the light of Article XII of the same treaty, which provides that all stations, installations, space vehicles and other equipment on the Moon and other celestial bodies shall be open to representatives of any other States parties to the Outer Space Treaty on a basis of reciprocity." ${ }^{27}$ The term "free access" of the Article I would consequently be read in the meaning that there shall be free access to all areas of outer space and celestial bodies at all times, except as ruled in Article XII. ${ }^{58}$ Thus, Article I emphasizes the nonsovereignty rule on the Moon.

\section{Conclusion}

In regard to similarities, on earth, sovereignty may not be claimed on the Arctic, Antarctic, seabed and ocean floor. The same rule applies on moon, on which no sovereignty may be claimed. Furthermore, it is affirmed that the Arctic, Antarctic, seabed and ocean floor on earth, including the moon are the common heritages of mankind. Consequently, all conduct on those areas shall be beneficial for mankind with no exception.

In regard to differences, there are existing claims of sovereignty on Arctic and Antarctic regions. However, no relevant legal instrument specifically provides whether or not such existing claims must be rejected. Meanwhile, there is no any existing claim of sovereignty on seabed, ocean floor and on moon. Consequently, it is not necessary for any legal instrument concerning seabed, ocean floor and moon to provide for the status of existing claim. On the other issue, there is no any legal instrument, concerning the Arctic, Antarctic, seabed and ocean floor, specifically provides for "free access" to other state's base each other. While on moon, there exists such regulation. When any base is established on the moon, the provision of "free access" must be applied, to which it must be open to other representatives of other states on the basis of reciprocity and international cooperation.

\section{References}

56 Leo Gross, 1984, "Development of International Law by the United Nations", Essays on International Law and Organization, Vol. 1, Brill, Leiden, p. 251; Martin Dixon I, op. cit., p. 269.

57 Edmund Jan Ozmanczyk, 2003, Encyclopedia of the United Nations and International Agreements: $N$ to $S$, Taylor \& Francis, Oxfordshire, p. 1713; Thomas Graham Jr and Damien J. LaVera, 2011, Cornerstones of Security: Arms Control Treaties in the Nuclear Era, University of Washington Press, Washington, p. 38.

58 Paul G. Dembling and Daniel M. Arons, 1967, "The Evolution of the Outer Space Treaty", Journal of Air Law and Commerce, Vol. 33, pp. 430-431. 


\section{Books}

American Society of International Law, 1970, "Documents Concerning Canadian Legislation on Arctic Pollution and Territorial Sea and Fishing Zones", International Legal Materials, Vol. 9, Cambridge University Press, Cambridge.

Amos Enabulele and Bright Bazuaye, 2014, Teachings on Basic Topics in Public International Law, Amos Enabulele.

Andre De Hoogh, 1996, Obligation Erga Omnes and International Crimes: A Theoretical Inquiry Into the Implementation and Enforcement of the International Responsibility of States, Martinus Nijhoff Publishers, Leiden.

Ben Saul and Tim Stephens, 2015, Antarctica in International Law, Bloomsbury Publishing, London.

Bryan A. Garner (ed), 2009, Black's Law Dictionary, 9 ${ }^{\text {th }}$ edition, Thomson Reuters, Toronto.

Cairo A. R. Robb et. al., 1999, International Environmental Law Reports, Vol. 1, Cambridge University Press, Cambridge.

Charles Lawson, 2012, Regulating Genetic Resources: Access and Benefit Sharing in International Law, Edward Elgar Publishing, Cheltenham.

Christian J. Tams and James Sloan, 2013, The Development of International Law by the International Court of Justice, Oxford University Press, Oxford.

Christian Tomuschat, 1993, Modern Law of Self Determination, Martinus Nijhoff Publishers, Leiden.

Christopher C. Joyner, 1992, Antarctica and the Law of the Law of the Sea, Martinus Nijhoff Publishers, Leiden.

D. P. O'Connell, 1970, International Law, $2^{\text {nd }}$ edition, Stevens, London.

Donald R. Rothwell, 1996, The Polar Regions and the Development of International Law, Cambridge University Press, Cambridge.

Edmund Jan Ozmanczyk, 2003, Encyclopedia of the United Nations and International Agreements: $N$ to S, Taylor \& Francis, Oxfordshire.

Elizabeth Fisher, Bettina Lange and Eloise Scotford, 2013, Environmental Law: Text, Cases and Materials, Oxford University Press, Oxford.

Francisco Orrego Vicuna, 1988, Antarctic Mineral Exploitation: The Emerging Legal Framework, Cambridge University Press, Cambridge.

G. H. Hackworth, 1940, Digest of International Law, Vol. 1, Washington, DC.

Gabriel Lafferranderie and Daphne Crowther, 1997, Outlook on Space Law Over the Next 30 Years, Martinus Nijhoff Publishers, Leiden.

Gianfranco Tamburelli, 2008, The Antarctic Legal System: The Protections of the Environment of the Polar Regions, Giuffre Editore, Milan.

Gijsbertha Cornelia Maria Reijnen, 1992, The United Nations Space Treaties Analyzed, Atlantica Seguier Frontieres, Paris. 
Gunter Hoog and Angela Steinmetz, 1993, International Conventions on Protection of Humanity and Environment, Walter de Guyter, Berlin.

Hugo Caminos, 2017, Law of the Sea, Routledge, London.

Klaus J. Dodds and Kathryn Yusoff, 2004, Settlement and Unsettlement in Aotearoa/New Zealand and Antarctica, University of London, Surrey.

Leo Gross, 1984, "Development of International Law by the United Nations", Essays on International Law and Organization, Vol. 1, Brill, Leiden.

Luis S. Mericq, 1987, Antarctica: Chile's Claim, National Defense University Press, Washington.

M. Sornarajah, 2010, The International Law on Foreign Investment, Cambridge University Press, Cambridge.

Malcolm N. Shaw, 2003, International Law, $5^{\text {th }}$ edition, Cambridge University Press, Cambridge.

Malcolm N. Shaw, 2008, International Law, $6^{\text {th }}$ edition, Cambridge University Press, Cambridge.

Marietta Benko et. al., 2005, Space Law: Current Problems Perspective for Future Regulation, Eleven International International Publishing, Hague.

Martin Dixon, Robert McCoquodale and Sarah Williams, 2011, Cases and Materials on International Law, Oxford University Press, Oxford.

Martin Dixon, Robert McCoquodale and Sarah Williams, 2016, Cases and Materials on International Law, Oxford University Press, Oxford.

Nguyen Quoc Dinh, P. Daillier and A. Pellet, 2002, Droit International Public, $7^{\text {th }}$ edition, Paris.

Obed Y. Asamoah, 2012, The Legal Significance of the Declarations of the General Assembly of the United Nations, Springer, Berlin.

Ole Kristian Fauchald, David Hunter and Wang Xi, 2011, Yearbook of International Environmental Law 2009, Vol. 20, Oxford University Press, Oxford.

Paul Stephen Dempsey, 2008, Public International Air Law, Mcgill University Institute and Centre for Research in Air and Space Law, Montreal.

Peter Mahmud Marzuki, 2009, Penelitian Hukum, Kencana Prenada Media Group, Jakarta.

Petra Butler and Caroline Morris, 2017, Small States in a Legal World, Springer, Berlin.

Philip Kunig, 2008, “Intervention, Prohibition of", Max Planck Encyclopedia of Public International Law, Oxford University Press, Oxford.

R. Y. Jennings and A.D. Watts, 1992, Oppenheim's International Law, Vol. 1, $9^{\text {th }}$ edition, Oxford University Press, Oxford.

Ram S. Jakhu, 2016, Routledge Handbook of Space Law, Taylor \& Francis, Oxfordshire. 
Robin Rolf Churchill and Alan Vaughan Lowe, 1983, The Law of the Sea, Manchester University Press, Manchester.

Rosanne van Alebeek, 2008, The Immunity of States and Their Officials in International Criminal Law and International Human Rights Law, E. M. Meijers Instituut, Leiden.

Shigeru Oda, 1972, The International Law of the Ocean Development: Basic Documents, Volume 1, Brill, Leiden.

Silke Marie Christiansen, 2016, Climate Conflicts - A Case of International Environmental and Humanitarian Law, Springer, Berlin.

Soerjono Soekanto and Sri Mamudji, 2006, Penelitian Hukum Normatif Suatu Tinjauan Singkat, Raja Grafindo Persada, Jakarta.

Surya Prakash Sharma, 1997, Territorial Acquisition, Disputes and International Law, Martinus Nijhoff Publishers, Leiden.

Susan Breau, 2013, Q E A Revision Guide International Law 2013 and 2014, Oxford University Press, Oxford.

Thomas Gangale, 2009, The Development of Outer Space: Sovereignty and Property Rights in International Space Law, ABC-CLIO, California.

Thomas Graham Jr and Damien J. LaVera, 2011, Cornerstones of Security: Arms Control Treaties in the Nuclear Era, University of Washington Press, Washington.

Tosaporn Leepuengtham, 2017, The Protection of Intellectual Property Rights in Outer Space Activities, Edward Elgar Publishing, Cheltenham.

United Nations General Assembly, 1997, Key Resolutions of the United Nations General Assembly 1946-1996, Cambridge University Press, Cambridge.

Vincent Coussirat-Coustaere and Pierre Michel Eissemann, 1989, Repertory of International Arbitral Jurisprudence, Vol. 2, Brill, Leiden.

Yoshifumi Tanaka, 2012, The International Law of the Sea, Cambridge University Press, Cambridge.

\section{Treaties \& Conventions}

Agreement Governing the Activities of States on the Moon and Other Celestial Bodies.

Antarctic Treaty 1959.

Charter of the United Nations 1945.

Convention on the Conservation of Antarctic Marine Living Resources 1980.

Convention on the Law of the Sea 1982.

Treaty on the Principles Governing the Activities of States in the Exploration and Use of Outer Space, including the Moon and Other Celestial Bodies 1967.

\section{United Nations Documents}

UN Doc. A/41/722, 17 November 1986, Question of Antarctica. 
UNGA Res. 1721 A (XVI), 20 December 1961, International Cooperation in the Peaceful Uses of Outer Space.

UNGA Res. 2749 (XXV), 17 December 1970, Declaration of Principles Governing the Seabed and the Ocean Floor, and the Subsoil Thereof, beyond the Limits of National Jurisdiction.

UNGA Res. 51/122, 13 December 1996, Declaration on International Cooperation in the Exploration and Use of Outer Space for the Benefit and in the Interest of All States, Taking into Particular Account, the Needs of Developing Countries.

\section{Cases Law}

Military and Paramilitary Activities in and against Nicaragua (Nicaragua v. United States of America), Merits, Judgment of 27 June 1986, I.C.J. Reports 1986.

United Nations Office of Legal Affairs, 1928, "Island of Palmas" Report of International Arbitral Awards, Vol. 2.

\section{Articles}

Adriana Fabra and Virginia Gascon, 2008, "The Convention on the Conservation of Antarctic Marine Living Resources (CCAMLR) and the Ecosystem Approach", The International Journal of Marine and Coastal Law, Vol. 23, Martinus Nijhoff Publishers, Leiden.

Balch, "The Arctic and Antarctic Regions and the Law of Nations", American Journal of International Law, Vol. 4, 1910.

Bernard H. Oxman, 1989, "The high Seas and the International Seabed Area", Michigan Journal of International Law, Vol. 10.

Bin Cheng, 1999, “Outer Void Space: The Reason for This Neologism in Space Law", Australian International Law Journal.

Carol R. Buxton, 2004, "Property in Outer Space: The Common Heritage of Mankind Principle vs. the First in Time, First in Right, Rule of Property", Journal of Air Law and Commerce, Vol. 69.

G. Triggs, 1981, "Australian Sovereignty in Antarctica - Part I", Melbourne University Law Review, Vol. 13.

G. Triggs, 1982, “Australian Sovereignty in Antarctica - Part II", Melbourne University Law Review, Vol. 13.

I. Head, 1962, "Canadian Claims to Territorial Sovereignty in the Arctic Regions", McGill Law Journal, Vol. 9.

J. H. W. Verzijl, 1970, International Law in Historical Perspective, Leiden, Vol. 3.

John E. Noyes, 2012, “The Common Heritage of Mankind: Past, Present, and Future", Denver Journal of International Law and Policy, Vol. 40.

Malcolm N. Shaw, 1982, "Territory in International Law", Netherlands Yearbook of International Law, Vol. 13. 
Marcelo Kohen, 2012, “The Principle of Non-Intervention 25 Years after the Nicaragua Judgment", Leiden Journal of International Law, Vol. 25.

Odd Gunnar Skagestad, 2013, "Sovereignty, Jurisdiction and Cooperation: The Antarctic Treaty, Preconditions, Substance and Future Relevance", New Ground Research Journal of Scientific Research and Articles, Vol. 1.

Paul G. Dembling and Daniel M. Arons, 1967, "The Evolution of the Outer Space Treaty", Journal of Air Law and Commerce, Vol. 33.

Phillip Bender, 2007, "A State of Necessity: IUU Fishing in the CCAMLR Zone", Ocean and Coastal Law Journal, Vol. 13.

Ricky J. Lee, 2004, “Article II of the Outer Space Treaty: Prohibition of State Sovereignty, Private Property Rights, or Both?", Australian Journal of International Law, Vol. 11.

Stephen Gorove, "Interpreting Article II of the Space Treaty", Fordham Law Review, Vol. 37.

W. Lakhtine, "Rights over the Arctic", American Journal of International Law, Vol. 24, 1930.

Yoshifumi Tanaka, 2011, "Protection of Community Interests in International Law: The Case of the Law of the Sea", Max Planck Yearbook of United Nations Law, Vol. 15.

\section{Internet}

Amal Nur Ngazis, 2016, “13-12-1972: Misi Terakhir Manusia Mengorbit Bulan", URL: http://teknologi.news.viva.co.id/news/read/85867413-12-1972-misi-terakhir-manusia-mengorbit-bulan accessed on 3 May 2017.

Andrew Griffin, 2017, “China and Europe to Build A Base on the Moon and Launch Other Projects into Space", URL: http:/ / www.independent.co.uk/news/science/moon-base-outpostchina-europe-chinese-space-agency-collaboration-togethera7702936.html accessed on 4 May 2017.

David Hitt, 2015, "What Was the Appolo Program?", NASA Knows (Grades 5-8), URL: https://www.nasa.gov/audience/forstudents/58/features/nasa-knows/what-was-apollo-program-58.html accessed on 3 May 2017.

Edd Gent, 2018, "Moon Bases Being Planned Now May Show Us How to Live Off-Planet", URL: https://www.nbcnews.com/mach/science/moon-bases-beingplanned-now-may-show-us-how-live-ncna855826 accessed on 22 September 2018.

Jasper Hamill, 2017, "China and Europe Want to Build A Moon Base Together", URL: http://nypost.com/2017/04/27/china-and-europewant-to-build-a-moon-base-together/ accessed on 4 Mei 2017.

Matt Williams, 2016, "Moonbase by 2022 for \$10 Billion, Says NASA", URL: https:// www.universetoday.com/128011/moonbase-2022-10-billionsays-nasa/ accessed on 4 May 2017. 
NASA,

2011,

“Apollo

$17^{\prime \prime}$,

URL:

https://www.nasa.gov/mission_pages/apollo/missions/apollo17.ht $\mathrm{ml}$ accessed on 3 May 2017.

NASA, 2012,

"Apollo

$1^{\prime \prime}$,

URL: https://www.nasa.gov/mission_pages/apollo/missions/apollo1.ht $\mathrm{ml}$ accessed on 3 May 2017.

Richard Gray, 2016, “We Could Be Living on the Moon by 2022: NASA Claims A 'Cheap' \$10 Billion Lunar Base Will Be Ready for Humans in Just Six Years", URL: http:/ /www.dailymail.co.uk/sciencetech/article-3507665/Couldliving-moon-2022-Nasa-scientists-reveal-plans-build-lunar-base-sixyears-10-billion.html accessed on 3 May 2017.

The Guardian, 2017, "Elon Musk: SpaceX Can Colonize Mars and Build Moon Base," URL: https://www.theguardian.com/technology/2017/sep/29/elonmusk-spacex-can-colonise-mars-and-build-base-on-oon accessed on 22 September 2018. 